\title{
IMMUNOREACTIVITY OF CYTOKERATINS 7 AND 20 IN GOBLET CELLS AND COLUMNAR BLUE CELLS IN PATIENTS WITH ENDOSCOPIC EVIDENCE OF BARRETT'S ESOPHAGUS
}

\author{
João Carlos CANTARELLI Jr. ${ }^{1,2}$, Renato Borges FAGUNDES ${ }^{1,2}$, Luise MEURER ${ }^{1,3}$, \\ Marta Pires da ROCHA ${ }^{4}$, André NICOLA ${ }^{3}$ and Cleber Dario Pinto KRUEL ${ }^{1}$
}

\begin{abstract}
Context - Barrett's esophagus is characterized by the presence of goblet cells. However, when alcian-blue is utilized, another type of cells, called columnar blue cells, is frequently present in the distal esophagus of patients with endoscopic evidence of Barrett's esophagus. Cytokeratin 7 and 20 immunoreactivity has been previously studied in areas of intestinal metaplasia at the esophagogastric junction. However, the expression of these cytokeratins in columnar blue cells has not been characterized. Objective - To compare the expression of cytokeratin 7 and 20 in goblet cells and columnar blue cells in patients with endoscopic evidence of Barrett's esophagus. Methods - Biopsies from 86 patients with endoscopic evidence of Barrett's esophagus were evaluated. The biopsies were stained for cytokeratin 7 and 20 . Results - Goblet cells were present in 75 cases and columnar blue cells in 50 cases. Overall, cytokeratin 7 expression was similar in goblet cells and columnar blue cells $(P=0.25)$, while cytokeratin 20 was more common in goblet cells $(P<0.001)$. In individuals with both cell types, however, cytokeratin 7 staining was the same in goblet and columnar blue cells in $95 \%$ of the cases, and cytokeratin 20 staining was the same in $77 \%$. Conclusion - Goblet cells and columnar blue cells have similar immunohistochemical staining patterns for cytokeratins 7 and 20 in patients with endoscopic evidence of Barrett's esophagus.
\end{abstract}

HEADINGS - Barrett esophagus. Keratins. Metaplasia. Goblet cells. Alcian blue.

\section{INTRODUCTION}

Barrett's esophagus (BE) is considered a risk factor for esophageal adenocarcinoma, whose incidence in the Western world has been increasing rapidly in the last decades ${ }^{(8,9,28,29,32)}$. Histologically, BE represents an incomplete form of intestinal metaplasia, characterized by the presence of goblet cells in hematoxylin and eosin (H-E) staining. These cells contain acid mucins, which can be detected easily with the use of alcian blue stain at $\mathrm{pH} 2,5(\mathrm{AB})^{(1,16)}$. Because the risk for esophageal cancer, patients with BE should be enrolled in a program of endoscopic surveillance for dysplasia and adenocarcinoma ${ }^{(5,9,29,32)}$.

However, the histological diagnosis of the intestinal metaplasia on routine H-E staining is not always simple. Gastric cardia-type mucosa may contain distended cells with a goblet configuration ("pseudoglobet" cells) and pose a source of overdiagnosis of intestinal metaplasia and false-positive diagnosis of BE. When there is doubt about the nature of goblet-shaped cells, AB stain should be applied because these cells do not contain acid mucin ${ }^{(17}$, ${ }^{18)}$. Nevertheless, if AB is applied, there are cells in the surface of the metaplastic epithelium that are as common or more common than the goblet cells and which look similar to gastric columnar cells when stained with HE, but, unlike gastric columnar cells, they stain positively with $\mathrm{AB}^{(17,18,23)}$. These cells are called columnar blue cells, and according to some authors they may represent a transitional type of metaplastic cells, intermediate between gastric columnar cells and goblet cells ${ }^{(17,33)}$. Because of this possibility, the columnar blue cells have generated controversy in the histological diagnosis of $\mathrm{BE}^{(3,10,11,16)}$.

Financial source: Fund of Incentive to the Research (FIPE) - "Hospital de Clínicas", Porto Alegre, RS, Brazil.

${ }^{1}$ Postgraduate program: Sciences in Gastroenterology, "Universidade Federal do Rio Grande do Sul" - UFRGS; ${ }^{2}$ Department of Gastroenterology, "Universidade Federal de Santa Maria" - UFSM; ${ }^{3}$ Department of Pathology, UFRGS, Porto Alegre, RS, Brazil; 'Department of Pathology, UFSM. , Santa Maria, RS, Brazil.

Correspondence: Dr. L. Meurer - Serviço de Patologia - Hospital de Clínicas de Porto Alegre - Rua Ramiro Barcelos, 2350 - Bairro Rio Branco - $97105-900$ - Porto Alegre RS, Brazil. E-mail: Imeurer@hcpa.ufrgs.br 
It is important to identify the relationship between goblet cells and columnar blue cells, and the relationship of both cell types to cancer risk, to optimize the diagnosis of $\mathrm{BE}$ and the inclusion of patients in programs of endoscopic surveillance. Markers that can show similarities and differences between these two cell types may help clear up these uncertainties. Immunohistochemical expression of cytokeratins 7 (CK7) and 20 (CK20) has been studied in areas of intestinal metaplasia at the esophagogastric junction. Cytokeratins constitute the subunits I and II of intermediate filaments, which are one of the main components of the cellular skeleton. All simple and complex epithelia can be classified according to their cytokeratin expression. CK7 is not usually expressed in the epithelium of the gastrointestinal tract, while CK20 expression is common in the gastric foveolar epithelium and in intestinal epithelium ${ }^{(4)}$. A previous study by ORMSBY et al. ${ }^{(24)}$ suggested that specific patterns of CK7/CK20 reactivity could help discriminate between Barrett's esophagus and intestinal metaplasia of the cardia. Other authors tried to reproduce

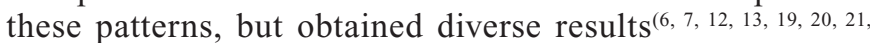
$25,27,30,31)$. Until now, the expression of these cytokeratins has not been reported separately in the goblet cells and the columnar blue cells of individual cases, so it has been hard to evaluate whether the two cell types are similar or different in their expression of these proteins. Therefore, the aim of this study was to evaluate and compare the immunoreactivity of CK7 and CK20 in the goblet cells and columnar blue cells of individual patients with endoscopic evidence of Barrett's esophagus.

\section{METHODS}

\section{Selection of the cases}

This study was approved by the Ethics in Research Committee of Hospital de Clínicas, Porto Alegre, RS, Brazil. Endoscopy and pathology files were reviewed from all patients seen in the years 2002 and 2003. Biopsies obtained from patients with upper GI endoscopy suggestive of Barrett's esophagus were stained with $\mathrm{H}-\mathrm{E}$ and $\mathrm{AB}$ and were reviewed for the identification of goblet cells and columnar blue cells. Endoscopic evidence of Barrett's esophagus was defined as visualization of columnar epithelium above the esophagogastric junction, and was subcategorized as long-segment (extension $>3 \mathrm{~cm}$ ) or short-segment $(<3 \mathrm{~cm})$. Goblet cells were defined as ABpositive cells with distended lateral borders and compressed basal nuclei. Columnar blue cells were defined as columnar cells which have an appearance similar to gastric superficial cells on $\mathrm{H}-\mathrm{E}$ but have cytoplasm staining positively on $\mathrm{AB}^{(23)}$. Only cells in the surface epithelium were evaluated in this study, since columnar blue cells can be found normally in foveolar epithelium. All patients with a biopsy containing at least epithelial areas with a minimum of 10 goblet cells, 10 columnar blue cells, or both were included in the study, and one biopsy per patient was stained immunohistochemically for CK7 and CK20. Epithelial areas with only AB-negative cells were not included in the analysis.

\section{Immunohistochemical technique}

Serial 4 micrometer sections were stained with $\mathrm{HE}, \mathrm{AB}$, CK7, and CK20. The slides were deparaffinized and rehydrated. The inhibition of endogenous peroxidase was achieved with hydrogen peroxide at $5 \%$ in distilled water. Antigen retrieval was performed in a microwave oven at full power with citrate buffer at $\mathrm{pH} 6.0$ for 21 minutes. A solution of 5\% powdered skimmed milk in phosphate-buffered saline (PBS) was used to block nonspecific reactions. Anti-cytokeratin 7 (clone OVTL 12/30, Biogenex) and anti-cytokeratin 20 (clone Ks 20.8, Biogenex) antibodies were applied, both at a dilution of 1:100. Detection of primary antibodies was achieved by streptavidinbiotin complex, and 3-3-diaminobenzidine-tetrahydrochloride (DAB) was used as the chromogen. The slides were counterstained with hematoxylin. Positive controls were used for each of the antibodies (breast tissues for CK7 and colon tissues for CK20), while in the negative controls the buffer solution was substituted for the primary antibody.

\section{Evaluation of immunoreactivity}

CK7 and CK20 immunoreactivity (positive or negative) was determined by evaluation of membranous and cytoplasmic staining of the cells viewed at high magnification (400x). Nonspecific or background staining was considered as negative. Cases with more than $10 \%$ of the goblet cells or the columnar blue cells staining positively were considered positive. In all cases, the cytokeratin reactivity was compared to the $\mathrm{AB}$ findings on serial sections. The slides were examined by two independent pathologists (LM and MPR). In discordant or doubtful cases a consensus was reached between the two observers after joint review. The pathologists had no knowledge of the patients' endoscopic findings.

\section{Statistical analysis}

Fischer's exact test was used to compare the proportions of goblet cells and columnar blue cells stained by CK 7 and CK20. To evaluate the interobserver agreement in the histological identification of the studied cells and in the interpretation of the immunohistochemical results, kappa (k) statistics were calculated. Interobserver agreement was classified as poor $(<0.20)$, fair $(0.21-0.40)$, moderate $(0.41-0.60)$, good $(0.61-0.80)$, or very $\operatorname{good}(>0.80)^{(15)}$.

\section{RESULTS}

The study included one biopsy from each of 86 patients. Fifty-nine biopsies $(68.6 \%)$ were from patients suspected of having long-segment $\mathrm{BE}$ and 27 biopsies (31.4\%) were from patients suspected of having short-segment $\mathrm{BE}$. The frequencies of both cell types in the biopsies and their relationship with the endoscopic findings are summarized in Table 1. Inter-observer agreement (kappa) was 1.00 for the identification of goblet cells, and it was 0.75 for the identification of columnar blue cells. In 36 cases, only goblet cells were observed. In 11 cases, only columnar blue cells were found, and 8 of these cases had the endoscopic appearance of short-segment BE. In the 39 
remaining cases, there were areas that contained both goblet cells and columnar blue cells. Overall, goblet cells were present in 75 biopsies $(87.2 \%)$, while the columnar blue cells were seen in 50 biopsies $(58.1 \%)$.

TABLE 1. Frequencies of the goblet cells (GC), columnar blue cells (CB), or both cells (GC/CB) in biopsies from patients with endoscopic evidence of long-segment Barrett's esophagus (LSBE) and short-segment Barrett's esophagus (SSBE)

\begin{tabular}{lcccc}
\hline & $\mathrm{GC}$ & $\mathrm{CB}$ & $\mathrm{GC} / \mathrm{CB}$ & Total \\
\hline \multirow{2}{*}{ LSBE } & 27 & 3 & 29 & 59 \\
& $(31.4 \%)$ & $(3.5 \%)$ & $(33.7 \%)$ & $(68.6 \%)$ \\
SSBE & 9 & 8 & 10 & 27 \\
& $(10.5 \%)$ & $(9.3 \%)$ & $(11.6 \%)$ & $(31.4 \%)$ \\
Total & 36 & 11 & 39 & \\
\hline
\end{tabular}

Interobserver agreement (kappa) values for CK7 expression in goblet cells and columnar blue cells were 0.85 and 0.90 , respectively, while these values for CK20 expression were 0.93 for the goblet cells and 0.74 for the columnar blue cells.

Comparisons of CK7 and CK20 reactivity in the goblet and columnar blue cells are shown in Table 2. Overall, CK7 was expressed in the goblet cells in $77.3 \%$ of the biopsies containing goblet cells, and it was expressed in the columnar blue cells in $86.0 \%$ of the biopsies containing columnar blue cells ( $P$-value for the difference $=0.25$ ). CK20 was expressed in the goblet cells in $89.3 \%$ of cases containing these cells, and it was expressed in columnar blue cells in $62.0 \%$ of the cases containing these cells $(P<0.001)$ (Figure 1).

The concordance of CK7 and CK20 reactivity patterns in the 39 cases with both cell types is shown in Table 3. In $94.9 \%$ of these cases, CK7 staining was the same (positive or negative) in the goblet cells and the columnar blue cells, and in $77.0 \%$ of the cases, the CK20 staining was the same in the two cell types.

TABLE 2. Reactivity of CK7 and CK20 in cases with goblet cells only (GC), columnar blue cells only (CB) or both cells present (GC/CB)

\begin{tabular}{|c|c|c|c|c|c|c|}
\hline & \multirow[t]{2}{*}{$\mathrm{n}$} & & \multicolumn{2}{|c|}{ CK7 } & \multicolumn{2}{|c|}{ CK20 } \\
\hline & & & Positive & Negative & Positive & Negative \\
\hline GC & 36 & & $\begin{array}{c}23 \\
(63.9 \%)\end{array}$ & $\begin{array}{c}13 \\
(36.1 \%)\end{array}$ & $\begin{array}{c}33 \\
(91.7 \%)\end{array}$ & $\begin{array}{c}3 \\
(8.3 \%)\end{array}$ \\
\hline СВ & 11 & & $\begin{array}{c}10 \\
(90.9 \%)\end{array}$ & $\begin{array}{c}1 \\
(9.1 \%)\end{array}$ & $\begin{array}{c}6 \\
(54.5 \%)\end{array}$ & $\begin{array}{c}5 \\
(45.5 \%)\end{array}$ \\
\hline \multirow{2}{*}{$\mathrm{GC} / \mathrm{CB}$} & \multirow{2}{*}{39} & GC & $\begin{array}{c}35 \\
(89.7 \%)\end{array}$ & $\begin{array}{c}4 \\
(10.3 \%)\end{array}$ & $\begin{array}{c}34 \\
(87.2 \%)\end{array}$ & $\begin{array}{c}5 \\
(12.8 \%)\end{array}$ \\
\hline & & $\mathrm{CB}$ & $\begin{array}{c}33 \\
(84.6 \%)\end{array}$ & $\begin{array}{c}6 \\
(15.4 \%)\end{array}$ & $\begin{array}{c}25 \\
(64.1 \%)\end{array}$ & $\begin{array}{c}14 \\
(35.9 \%)\end{array}$ \\
\hline GC TOTAL & 75 & & $\begin{array}{c}58 \\
(77.3 \%)\end{array}$ & $\begin{array}{c}17 \\
(22.7 \%)\end{array}$ & $\begin{array}{c}67 \\
(89.3 \%)\end{array}$ & $\begin{array}{c}8 \\
(10.7 \%)\end{array}$ \\
\hline CB TOTAL & 50 & & $\begin{array}{c}43 \\
(86.0 \%)\end{array}$ & $\begin{array}{c}7 \\
(14.0 \%)\end{array}$ & $\begin{array}{c}31 \\
(62.0 \%)\end{array}$ & $\begin{array}{c}19 \\
(38.0 \%)\end{array}$ \\
\hline
\end{tabular}



FIGURE 1. Alcian blue stain, cytokeratin 7 and cytokeratin 20 expression in goblet cells (A, B, C) and columnar blue cells (D, E, F)

TABLE 3. Expression patterns of $\mathrm{CK} 7$ and CK20 in the goblet cells (GC) and the columnar blue cells (CB) in individual patients who had both cells types

\begin{tabular}{cccccc}
\hline & $\mathrm{GC}+/ \mathrm{CB}+$ & $\mathrm{GC}+/ \mathrm{CB}-$ & $\mathrm{GC}-/ \mathrm{CB}+$ & $\mathrm{GC}-/ \mathrm{CB}-$ & TOTAL \\
\hline CK7 & 33 & 2 & - & 4 & 39 \\
& $(84.6 \%)$ & $(5.1 \%)$ & & $(10.3 \%)$ & \\
CK20 & 25 & 9 & - & 5 & 39 \\
& $(64.2 \%)$ & $(23 \%)$ & & $(12.8 \%)$ & \\
\hline
\end{tabular}

\section{DISCUSSION}

The diagnosis of BE is suggested endoscopically by the identification of columnar epithelium in the distal esophagus and confirmed when goblet cells are identified in biopsies stained with $\mathrm{H}-\mathrm{E}^{(1,9,16,29,32)}$. However, when AB staining is applied, columnar cells located in the surface epithelium can also stain positively with $\mathrm{AB}$ (columnar blue cells), and they are a frequent finding during the histological examination of columnar epithelium of the distal esophagus ${ }^{(17,23,33)}$. In a topographic study of nine specimens of esophageal resections for BE-associated high-grade dysplasia or carcinoma, OFFNER et al. ${ }^{(23)}$ demonstrated that these cells were present in $85.7 \%$ of the histological sections, and sometimes they were more prevalent than the goblet cells in the superficial epithelium of the distal esophagus and esophagogastric junction. In spite of this, the presence of these cells is not sufficient to establish the diagnosis of $\mathrm{BE}$ when goblet cells are absent ${ }^{10}$, 
11, 18). On the other hand, if the columnar blue cells could be shown to be a pre-goblet stage, with increased risk for cancer development, this could have important implications for the diagnosis and management of BE. Therefore, the use of markers that can evaluate similarities and differences between columnar blue cells and goblet cells may have a real importance.

The cytokeratins are a family of structural proteins found in the cytoskeleton of epithelial cells. The expression of these cytokeratins depends on the type, location and differentiation of the epithelium. CK7, a marker of ductal differentiation, is not normally expressed in the epithelium of the digestive tract, while the expression of CK20, a marker of intestinal differentiation, is normally limited to the intestinal epithelium and the superficial gastric foveolar epithelium $^{(20,24)}$. The immunoreactivity of CK 7 and CK20 in intestinal metaplasia of the esophagogastric junction was initially described by ORMSBY et al. ${ }^{(24)}$ who defined different patterns of expression for BE (the Barrett pattern) and intestinal metaplasia of the cardia (the gastric pattern). The Barrett pattern showed $\mathrm{CK} 7$ reactivity in the surface epithelium and the superficial and deep glands, while the expression of CK20 was restricted to the surface epithelium and the superficial glands. The gastric pattern showed CK 7 reactivity to be absent or patchy, while CK20 expression occurred in the surface epithelium and the superficial and deep glands. In this original study, only the immunoreactivity of goblet cells was evaluated. The Barrett pattern was present in $94 \%$ of the specimens from esophageal resections and in $100 \%$ of the biopsies from patients with long-segment BE, and the gastric pattern was found in all of the biopsy specimens from the cardia and from gastric resections. Some subsequent studies appeared to reproduce these findings ${ }^{(19}$, $25,30,31)$. However, other authors presented discordant results and they concluded that these patterns are not useful to differentiate $\mathrm{BE}$ from intestinal metaplasia of the cardia ${ }^{(6,7,13,20,21,27)}$. In spite of these inconsistencies, these studies produced some outcomes that deserve further consideration. SHEARER et al. ${ }^{(31)}$ mentioned that similar patterns of CK7/CK20 expression were frequently observed in adjacent areas with and without goblet cells. MOHAMMED et al. ${ }^{(21)}$ identified the Barrett pattern in $55 \%$ of biopsies from inflamed or normal cardiac mucosa without evidence of intestinal metaplasia. GLICKMAN et al. ${ }^{(13)}$ noted that the immunophenotypes of the cardiac mucosa in patients with long-segment BE, shortsegment BE and normal esophagogastric junction were similar for Das-1 and CK7/CK20, but they were different from those of the gastric antral mucosa. DeMEESTER et al. ${ }^{\left({ }^{6}\right)}$ observed that the cardiac mucosa showed the Barrett pattern in $85 \%$ of their cases. In another study by ORMSBY et al. ${ }^{(25)}$ it was observed that areas of non-specialized columnar mucosa showed positive staining for CK 7 in $22 \%$ of the cases. In the same way, JOVANOVIC et al. ${ }^{(19)}$ reported a series of cases in which the non-intestinalized cardiac epithelium stained strongly positive for CK7 while the mucosa of the body and gastric antrum did not stain.
Together, these data show that similar patterns of CK7/CK20 expression are commonly observed in the columnar mucosa of the esophagogastric junction in the presence or absence of goblet cells. One possible explanation is that these areas are in transformation towards an intestinal phenotype ${ }^{(2,19,31)} \mathrm{BE}$ is composed not only of goblet cells, but also of columnar blue cells, which may correspond to immature goblet cells (pregoblet cells), and AB-negative columnar cells ${ }^{(22)}$. The surface epithelium of the cardia can also contain AB-positive columnar cells $^{(3,23)}$. Considering all of these findings, it is not surprising that columnar blue cells can have similar features in areas with and without goblet cells. The question is how the columnar blue cells and goblet cells are related to each other, in terms of differentiation and cancer risk.

In the current study of patients with endoscopic evidence of BE, we found similar CK7 and CK20 staining patterns in columnar blue cells and goblet cells. Most importantly, in individual cases which contained both cell types, the CK 7 and CK20 expression patterns were strikingly similar in the columnar blue and goblet cells. This concordance of cytokeratin protein expression is consistent with a close relationship between these two cell types, and suggests the importance of further evaluation of the possible role of columnar blue cells in the differentiation of goblet cells and the pathogenesis of adenocarcinomas in the distal esophagus and proximal stomach.

Other immunomarkers that have been studied in the intestinal metaplasia of BE include mucins ${ }^{(14,27)}$ and $\mathrm{Cdx} 2^{(26)}$ expression. In the mucin studies, $\mathrm{AB}$ staining in the columnar cells was not reported, so it was not possible to evaluate mucin reactivity in the columnar blue cells. In the $\mathrm{Cdx} 2$ study, $\mathrm{Cdx} 2$ expression was similar in goblet and columnar blue cells in cases in which both were present, and it was present but diminished in the columnar blue cells found in cases without goblet cells. The authors concluded that the columnar blue cells may not be indicative of intestinal metaplasia. Additional studies of mucins and $\mathrm{Cdx} 2$ expression in cases with endoscopic evidence of BE are warranted.

In conclusion, this study demonstrates that goblet cells and columnar blue cells have similar immunohistochemical staining patterns for CK7 and CK20 in patients with endoscopic evidence of BE, and the similarity of staining is especially evident in individual patients who have both cell types. This is consistent with the possibility that columnar blue cells represent an intermediate form on the differentiation pathway to goblet cells, a possibility that deserves further study.

\section{ACKNOWLEDGMENTS}

The authors thank Dr. Sanford M. Dawsey, MD, for his help in the English revision and his helpful comments in the preparation of this manuscript. 
Cantarelli Jr JC, Fagundes RB, Meurer L, Rocha MP, Nicola A, Kruel CDP. Imunoreatividade das citoqueratinas 7 e 20 nas células caliciformes e células colunares azuis em pacientes com evidência endoscópica de esôfago de Barrett. Arq Gastroenterol. 2009;46(2):127-31.

RESUMO - Contexto - Esôfago de Barrett é caracterizado pela presença de células caliciformes. Entretanto, quando "alcian blue" é utilizado, outro tipo de células, chamadas células colunares azuis, estão frequentemente presentes no esôfago distal de pacientes com evidência endoscópica de esôfago de Barrett. A imunoreatividade das citoqueratinas 7 e 20 tem sido estudada previamente em áreas de metaplasia intestinal na junção esôfago-gástrica. Entretanto, a expressão destas citoqueratinas nas células colunares azuis não foi caracterizada. Objetivo - Comparar a expressão das citoqueratinas 7 e 20 nas células caliciformes e células colunares azuis em pacientes com evidência endoscópica de esôfago de Barrett. Métodos - Biopsias de 86 pacientes com evidência endoscópica de esôfago de Barrett foram avaliadas. Estas foram coradas com citoqueratinas 7 e 20. Resultados - Células caliciformes estavam presentes em 75 casos e células colunares azuis em 50 casos. Ao todo, a expressão da citoqueratina 7 foi similar nas células caliciformes e células colunares azuis $(P=$ $0,25)$, enquanto que a da citoqueratina 20 foi mais comum nas células caliciformes $(P<0,001)$. Por outro lado, em indivíduos apresentando ambos os tipos de células, a coloração da citoqueratina 7 foi a mesma nas células caliciformes e células colunares azuis em $95 \%$ dos casos, e a coloração da citoqueratina 20 foi a mesma em 77\%. Conclusão - As células caliciformes e as células colunares azuis têm padrões similares de coloração imunoistoquímica para citoqueratina 7 e 20 em pacientes com evidência endoscópica de esôfago de Barrett.

DESCRITORES - Esôfago de Barrett. Queratinas. Metaplasia. Células caliciformes. Azul alciano.

\section{REFERENCES}

1. Carton E, Caldwell MTP, McDonald G, Rama D, Tanner WA, Reynolds JV. Specialized intestinal metaplasia in patients with gastro-oesophageal reflux disease. Br J Surg. 2000;87:116-21.

2. Chaves P, Cardoso P, De Almeida JCM, Pereira AD, Leitão CN, Soares J. Non-goblet cell population of Barrett's esophagus: an immunohistochemical demonstration of intestinal differentiation. Hum Pathol. 1999;30:1291-5.

3. Chen YY, Wang HH, Antonioli DA, Spechler SJ, Zeroogian JM, Goyal R, Shahsafaei A, Odze RD. Significance of acid-mucin-positive nongoblet columnar cells in the distal esophagus and gastroesophageal junction. Hum Pathol. 1999;30:1488-95.

4. Chu PG, Weiss LM. Keratin expression in human tissues and neoplasms. Histopathology. 2002;40:403-39.

5. DeMeester SR, DeMeester TR. Columnar mucosa and intestinal metaplasia of the esophagus. Fifty years of controversy. Ann Surg. 2000;231:303-21.

6. DeMeester SR, Wickramasinghe KS, Lord RV, Friedman A, Balaji NS, Chandrasoma PT, Hagen JA, Peters JH, DeMeester TR. Cytokeratin and DAS-1 immunostaining reveal similarities among cardiac mucosa, CIM, and Barrett's esophagus. Am J Gastroenterol. 2002;97:2514-23.

7. EL-Zimaity HMT, Graham DY. Cytokeratin subsets for distinguishing Barrett's esophagus from intestinal metaplasia in the cardia using endoscopic biopsy specimens. Am J Gastroenterol. 2001;96:1378-82.

8. Ertan A, Younes M. Barrett's esophagus. Dig Dis Sci. 2000;45:1670-73.

9. Falk GW. Barrett's esophagus. Gastroenterology. 2002;122:1569-91.

10. Faller G, Borschard F, Ell C, Seitz G, Stolte M, Walch A, R schoff J. Histopathological diagnosis of Barrett's mucosa and associated neoplasias: results of a consensus conference of the Working Group for Gastroenterological Pathology of the German Society for Pathology on 22 September 2001 in Erlangen. Virchows Arch. 2003;443:597-601

11. Fléjou JF. Barrett's esophagus: from metaplasia to dysplasia and cancer. Gut. 2005;54(Suppl I):i6-i12.

12. Flucke U, Steinborn E, Dries V, Mönig SP, Schneider PM, Thiele J, Hölscher AH, Dienes HP, Baldus SE. Immunoreactivity of cytokeratins (CK7, CK20) and mucin peptide core antigens (MUC1, MUC2, MUC5AC) in adenocarcinomas, normal and metaplastic tissues of distal esophagus, oesophago-gastric junction and proximal stomach. Histopathology. 2003;43:127-34.

13. Glickman JN, Wang H, Das K, Goyal RK, Spechler SJ, Antonioli D, Odze RD. Phenotype of Barrett's esophagus and intestinal metaplasia of the distal esophagus and gastroesophageal junction: an immunohistochemical study of cytokeratins 7 and 20, Das-1 and 45MI. Am J Surg Pathol. 2001;25:87-94.

14. Glickman JN, Shahsafaei A, Odze RD. Mucin core peptide expression can help differentiate Barrett's esophagus from intestinal metaplasia of the stomach. Am J Surg Pathol. 2003;27:1357-65.

15. Glickman JN, Ormsby AH, Gramlich TL, Goldblum JR, Odze RD. Interinstitutional variability and effect of tissue fixative on the interpretation of a Barrett cytokeratin 7/20 immunoreactivity pattern in Barrett esophagus. Hum Pathol. 2005;36:58-65.
16. Goldblum JR. The significance and etiology of intestinal metaplasia of esophagogastric junction. Ann Diagn Pathol. 2002;6:67-73.

17. Guindi M, Riddell RH. Histology of Barrett's esophagus and dysplasia. Gastrointest Endoscopy Clin N Am. 2003;13:349-68.

18. Haggitt RC. Pathology of Barrett's esophagus. J Gastrointest Surg. 2000;4:117-8.

19. Jovanovic I, Tzardi M, Mouzas IA, Micev M, Pesko P, Milosavljevic T, Zois M, Sganzos M, Delides G, Kanavaros P. Changing patterns of cytokeratins 7 and 20 expression from normal epithelium to intestinal metaplasia of the gastric mucosa and gastroesophageal junction. Histol Histopathol. 2002;17:445-54.

20. Liu GS, Gong J, Cheng P, Zhang J, Chang Y, Qiang L. Distinction between shortsegment Barrett's esophageal and cardiac intestinal metaplasia. World J Gastroenterol. 2005;11:6360-5.

21. Mohammed IA, Streutker CJ, Riddell RH. Utilization of cytokeratins 7 and 20 does not differentiate between Barrett's esophagus and gastric cardiac intestinal metaplasia. Mod Pathol. 2002;15:611-6.

22. Mueller J, Werner M, Stolte M. Barrett's esophagus: histopathologic definitions and diagnostic criteria. World J Surg. 2004;28:148-54.

23. Offner FA, Lewin KJ, Weinsten WM. Metaplastic columnar cells in Barrett's esophagus: a common and neglected cell type. Hum Pathol. 1996;27:885-9.

24. Ormsby AH, Goldblum JR, Rice TW, Richter JE, Falk GW, Vaezi MF, Gramlich TL. Cytokeratin subsets can reliably distinguish Barrett's esophagus from intestinal metaplasia of the stomach. Hum Pathol. 1999;30:288-94.

25. Ormsby AH, Vaezi MF, Richter JE, Goldblum JR, Rice TW, Falk GW, Gramlich TL. Cytokeratin immunoreactivity patterns in the diagnosis of short-segment Barrett's esophagus. Gastroenterology. 2000;119:683-90.

26. Phillips RW, Frierson HF, Moskaluk CA. Cdx2 as a marker of epithelial intestinal differentiation in the esophagus. Am J Surg Pathol. 2003;27:1442-7.

27. Piazuelo MB, Haque S, Delgado A, Du JX, Rodriguez F, Correa P. Phenotypic difference between esophageal and gastric intestinal metaplasia. Mod Pathol. 2004;17:62-74.

28. Reynolds JC, Rahimi P, Hirschi D. Barrett's esophagus: clinical characteristics. Gastroenterol Clin North Am. 2002;31:441-60.

29. Sampliner RE, The Practice Parameters Committee Of The American College of Gastroenterology. Update guidelines for the diagnosis, surveillance and therapy of Barrett's esophagus. Am J Gastroenterol. 2002;97:1888-95.

30. Sarbia M, Donner A, Franke C, Gabbert HE. Distinction between intestinal metaplasia in the cardia and Barrett's esophagus: the role of histology and immunohistochemistry. Hum Pathol. 2004;35:371-6.

31. Shearer C, Going J, Nellson L, Mackay C, Stuart RC. Cytokeratin 7 and 20 expression in intestinal metaplasia of the distal oesophagus: relationship to gastroesophageal reflux disease. Histopathology. 2005;47:268-75.

32. Spechler SJ. Barrett's esophagus. N Engl J Med. 2002;346:836-42.

33. Weinstein WM, Ippoliti AF. The diagnosis of Barrett's esophagus: goblets, goblets, goblets. Gastrointest Endosc. 1996;44:91-5.

Recebido em 26/8/2008 Aprovado em 14/11/2008 